\title{
Comparison of the opsonic activity of polyclonal and monoclonal antibodies raised against Salmonella minnesota strain R595
}

\author{
N. D. MEHTA, B. M. WILSON, N.T. RAPSON* and C. S. F. EASMON $\dagger$
}

Department of Medical Microbiology, Wright-Fleming Institute, St Mary's Hospital Medical School, London W2 1PG and Department of Experimental Immunobiology, Wellcome Research Laboratories, Langley Court, Beckenham, Kent BR3 $3 B S$

\begin{abstract}
Summary. Murine monoclonal antibodies and immune rabbit serum were raised against the rough mutant Salmonella minnesota strain R595. These antibodies were tested for their opsonic activity against the homologous strain and the smooth wild type $S$. minnesota by luminol-dependent chemiluminescence and a microscopic assessment of phagocytosis. Immune rabbit serum opsonised both strains. Treatment with normal rabbit serum inhibited the phagocytic uptake of $S$. minnesota R595. None of the monoclonal antibodies RE01 (anti-KDO), RE12 (anti-KDO) and RE23 (anti-lipid A) were opsonic. Unopsonised S. minnesota R595 stimulated marked chemiluminescence possibly because of its hydrophobic surface, but this was not reflected in increased uptake by phagocytic cells. Results obtained with luminoldependent chemiluminescence should be interpreted with caution when the opsonisation of rough bacterial strains or those with high surface hydrophobicity is being investigated.
\end{abstract}

\section{Introduction}

Despite potent antimicrobial agents and aggressive supportive therapy, the morbidity and mortality of sepsis and shock caused by gram-negative bacteria remains considerable. The severity of underlying disease and resistance to antimicrobial agents among bacteria such as Pseudomonas aeruginosa may, in part, account for this (Kreger et al. $1980 a, b)$. The poor outcome of sepsis with gramnegative bacteria has also been attributed to the systemic effects of lipopolysaccharide (LPS) against which antibiotics are ineffective (Kirkland and Ziegler, 1984).

One approach to this problem has been to use antisera raised against strains deficient in $O$ antigens, i.e., rough (R) mutants, in particular the rough mutants of Escherichia coli O111: B4 (E. coli J5) and Salmonella minnesota (S. minnesota R595), which only express lipid A and a portion of the core oligosaccharide as their LPS. Experimental work in animals (Ziegler et al., 1973; Braude et al., 1977; McCabe et al., 1977) and clinical studies (Ziegler $e t$ al., 1982; Baumgartner et al., 1985) have shown the protective efficacy of such antisera. Although the results of these studies are encouraging, not all

Received 3 March 1987; accepted 2 April 1987.

† Correspondence should be sent to Professor C. S. F. Easmon. investigators have found antisera to core glycolipid to be protective ( $\mathrm{Ng}$ et al., 1976; Greisman et al., 1978; Pennington and Menkes, 1981; Van Dijk et al., 1981). One problem in resolving these difficulties is that neither the precise molecular specificity nor the protective mechanism(s) of the antisera have been defined. Now that monoclonal antibodies to core glycolipid have been produced and are being investigated (Dunn et al., 1985; Teng et al., 1985), it is possible to address both these questions. One possible protective mechanism of core glycolipid antibody is by opsonisation leading to phagocytosis and intracellular killing. Ziegler et al. (1973) demonstrated that antiserum to $E$. coli $\mathrm{J} 5$ caused increased clearance of $E$. coli in agranulocytic rabbits. In this study we have investigated and compared the opsonic activity of polyclonal rabbit antiserum raised against formalin-killed $S$. minnesota R595 mutant, with three murine monoclonal antibodies directed against common core-glycolipid determinants from LPS of the same rough strain.

\section{Materials and methods}

\section{Bacterial strains}

S. minnesota wild type strain CN 1091 was obtained from the National Collection of Type Cultures, Colindale, 
London. S. minnesota $\mathrm{R} 595$ (Re), R4(Rd2), R5(Rc), $R 345(R b 2)$ and $R 60(R a)$ rough mutants were kindly provided by Dr C. Galanos, Freiburg, West Germany. Clinical isolates of gram-negative bacteria were obtained from the diagnostic bacteriology laboratory, St Mary's Hospital Medical School. These isolates were identified by either the API 20E (API Laboratory Products, Basingstoke) or N/F (Flow Laboratories Irvine, Scotland) system.

\section{Culture conditions}

Bacteria, apart from Neisseria meningitidis, Haemophilus influenzae and Bacteroides fragilis, were grown in Brain Heart Infusion Broth (Difco) at $37^{\circ} \mathrm{C}$ for $18 \mathrm{~h}$, harvested, washed and heat-killed at $100^{\circ} \mathrm{C}$ for $1 \mathrm{~h}$ in phosphatebuffered saline, $p \mathrm{H} 7 \cdot 2$ (PBS). $N$. meningitidis and $H$. influenzae were grown on chocolate agar plates and $B$. fragilis in Fastidious Anaerobe Broth (Lab M Ltd Bury). Heat-killed bacteria were resuspended in PBS at a concentration of $10^{9} \mathrm{cfu} / \mathrm{ml}$.

\section{Extraction and chemical treatment of LPS and lipid A}

LPS from smooth wild type strains was extracted by hot phenol-water (Westphal and Jann, 1965). LPS from rough mutant strains was extracted by phenol: chloroform: petroleum ether (PCP) (Galanos et al. 1969). Free lipid A was precipitated from R595 LPS with acetic acid $1 \% \mathrm{v} / \mathrm{v}$ (Galanos et al., 1971). Base-hydrolysed R595 LPS (BH-R595 LPS) and lipid A (BH-lipid A) were prepared by hydrolysing R595 LPS or lipid A with $0.2 \mathrm{M}$ sodium hydroxide at $100^{\circ} \mathrm{C}$ for $1 \mathrm{~h}$ (Rietschel et al., 1983).

\section{Reduction of the carboxyl groups in LPS}

Carbodiimide-activated carboxyl groups present on the 2-keto-3-deoxymannooctonate(KDO) moiety of R595 LPS were reduced with sodium-borohydride (Taylor and Conrad, 1972). Briefly, $25 \mathrm{mg}$ of 1-ethyl-3 (3-dimethylaminopropyl) carbodiimide (Sigma) was added to a $15-\mathrm{ml}$ suspension containing $10 \mathrm{mg}$ of R595 LPS. The mixture was agitated at room temperature and the $p \mathrm{H}$ of the suspension was maintained at 4.75 by the addition of $0.01 \mathrm{M} \mathrm{HCl}$. The reaction was allowed to proceed until the hydrogen ion uptake ceased at about $2 \mathrm{~h}$. The mixture was then transferred to a $50^{\circ} \mathrm{C}$ water bath and $5 \mathrm{ml}$ of $2 \mathrm{M}$ sodium-borohydride solution was added drop by drop. The $p \mathrm{H}$ of the mixture was maintained at $p \mathrm{H} 7$ with $0.01 \mathrm{M} \mathrm{HCl}$. After $3 \mathrm{~h}$ the mixture was transferred into dialysis tubing and extensively dialysed against distilled water (four 5-L changes over $24 \mathrm{~h}$ ). Finally the mixture was rotary evaporated to a small volume $(10 \mathrm{ml})$ and freeze dried. The material was designated reduced-R595 LPS.

\section{Preparation of BSA complexes}

The following antigens were complexed to bovine serum albumin (BSA; Sigma No. A7511): all rough and smooth forms of LPS, BH-R595 LPS, BH-lipid A, free lipid A and reduced-R595 LPS. The antigens were first dissolved in distilled water containing triethylamine $0.5 \% \mathrm{v} / \mathrm{v}$ to a concentration of $1 \mathrm{mg} / \mathrm{ml}$ by sonication for $30 \mathrm{~s}$. An equal volume of BSA solution $(10 \mathrm{mg} / \mathrm{ml})$ was added and complexes produced by rotary evaporation (Galanos et al. 1972). The dried residue was dissolved and evaporated again. Finally, the complexes were stored at $4^{\circ} \mathrm{C}$ in pyrogen-free distilled water at an LPS antigen concentration of $1 \mathrm{mg} / \mathrm{ml}$ (or BSA $10 \mathrm{mg} / \mathrm{ml}$ ) with sodium azide $0.01 \%$.

\section{Antiserum}

Four female New Zealand white rabbits $(2-2.5 \mathrm{~kg})$ were immunised intravenously with formalin-killed $S$. minnesota $\mathrm{R} 595$ cells $(4 \mathrm{mg} / \mathrm{ml}$ ) (Johns et al., 1983). Equal volumes of serum from each rabbit were pooled and stored at $-80^{\circ} \mathrm{C}$ in $0.5-\mathrm{ml}$ volumes. These were thawed just before use and never re-frozen.

\section{Production of monoclonal antibodies (MABs)}

Female, 8-week-old BALB/c mice were immunised intraperitoneally with $20 \mu \mathrm{g}$ of R595 LPS on day 0 and given a booster injection of a similar dose on day 7 . Three days later, spleen cells from mice with the highest antiR595 LPS titres, measured by a solid-phase radioimmunoassay, were fused with NSO myeloma cells (Galfre and Milstein, 1982). Supernates were screened for specific anti-R595 LPS antibodies and antibody secreting hybridomas subsequently cloned by limiting dilution. Cloned cells were grown up as ascites in BALB/c mice primed with pristane $(2,6,10,14$-tetramethylpentadecane; Aldrich) 14 days earlier. Ascitic fluids were tested for antibody activity either directly or after precipitation of immunoglobulin with sodium sulphate $27 \%$ w/v (Ivanyi and Davies, 1980). MAB RE23 was kindly produced and provided by Mr B. J. Appelmelk of the Free University, Amsterdam. RE23 was prepared by immunising mice with acetic acid-treated $\mathrm{R} 595$ cells.

\section{Radioimmunoassay ( $R I A$ )}

An RIA was used for the initial screening and subsequent characterisation of monoclonal and rabbit polyclonal antibodies. Briefly, flexible polyvinylchloride 96-well microtitration plates (Dynatech Laboratories, Inc., Alexandria, VA, USA) were coated with $50-\mu$ l volumes of R595 LPS at a concentration of $15 \mu \mathrm{g} / \mathrm{ml}$ in PBS and allowed to stand at $37^{\circ} \mathrm{C}$ for $2 \mathrm{~h}$ followed by overnight incubation at $4^{\circ} \mathrm{C}$. The plates were washed six times with PBS, and available sites blocked with gelatin 
(Difco) $0 \cdot 1 \% \mathrm{w} / \mathrm{v}$ in PBS. Control plates without antigen were similarly blocked with gelatin $0 \cdot 1 \%$. After washing, $50-\mu 1$ samples of five 10-fold dilutions of antibody in gelatin $0.1 \%$ were added to the plate in duplicate and incubated for $8 \mathrm{~h}$ at room temperature. Bound antibody was detected by adding $50 \mu \mathrm{l}$ of radio-iodinated globulin fraction of rabbit anti-mouse or goat anti-rabbit immunoglobulin $(20 \mu \mathrm{Ci} / \mu \mathrm{g}$; Wellcome Laboratories, Kent) diluted in BSA $3 \% \mathrm{w} / \mathrm{v}$ in PBS to give $5 \times 10^{4} \mathrm{cpm} /$ well, and incubated overnight at $4^{\circ} \mathrm{C}$. After washing with PBS, the plates were cut and the radioactivity retained in the wells counted for $1 \mathrm{~min}$ in a gamma-counter (NE/ 1600 Nuclear Enterprise, Edinburgh). Background counts were subtracted from the test counts and the results were expressed as $50 \%$ antibody titres (ABT50). The ABT50 was the titre that gave $50 \%$ specific binding of antibody to R595 LPS. A direct binding RIA was performed by adding $50 \mu \mathrm{l}$ of MAB or polyclonal antiserum at ABT50 to plates coated as above with 50- $\mu \mathrm{l}$ samples of various antigens (LPS antigens, $15 \mu \mathrm{g} / \mathrm{ml}$, or a suspension of heat-killed organisms; see above). The samples were always assayed in quadruplicate and the plates developed as described above. Background counts were subtracted and the data presented as mean cpm \pm SEM.

Inhibition studies were performed by pre-incubating $50 \mu \mathrm{l}$ of MAB or polyclonal antiserum at ABT50, with $50 \mu \mathrm{l}$ of either an LPS antigen $\left(10^{1}-10^{6} \mathrm{ng} / \mathrm{ml}\right)$ or heatkilled organisms $\left(10^{3}-10^{8} \mathrm{cfu} / \mathrm{ml}\right)$ at various concentrations for $4 \mathrm{~h}$ at $37^{\circ} \mathrm{C}$ before transferring the mixture $(100 \mu \mathrm{l})$ to microtitration wells coated with R595 cells or LPS. The assay was performed as described above and the data presented as mean percentage inhibition \pm SEM (at an inhibitor concentration of $15 \mu \mathrm{g} / \mathrm{ml}$ and at a 1 in 10 dilution of bacterial suspension). The percentage inhibition of binding was determined as: (cpm bound in absence of inhibitor - cpm bound with inhibitor/cpm bound in absence of inhibitor) $\times 100$. Inhibition was considered to be positive only when $\geq 20 \%$.

\section{Growth and opsonisation of bacteria}

For luminol-dependent chemiluminescence and phagocytosis experiments, washed overnight cultures $\left(10^{9} \mathrm{cfu} /\right.$ $\mathrm{ml}$ ) of wild type $S$. minnesota or R595 mutant were resuspended at $10^{9} \mathrm{cfu} / \mathrm{ml}$ in Hanks's Balanced Salt Solution without phenol red (HBSS: Gibco Ltd), $p \mathrm{H} 7 \cdot 3$, buffered with 25mM HEPES (N-2-hydroxyethylpiperazine-N'-2- ethanesulphonic acid; Gibco Ltd). To tubes containing $500 \mu \mathrm{l}$ of bacterial suspension $\left(10^{9} \mathrm{cfu} / \mathrm{ml}\right)$, $100 \mu \mathrm{l}$ of one of the following was added: normal rabbit serum (NRS), immune rabbit serum (IRS), heat-inactivated $\left(56^{\circ} \mathrm{C}, 30 \mathrm{~min}\right) \mathrm{NRS}$ or heat-inactivated IRS, each diluted to $10 \%$ in HBSS. Alternatively, $10 \mu \mathrm{g}$ of the globulin fraction of MAB, with or without $100 \mu \mathrm{l}$ of baby rabbit serum ( $10 \%$ in HBSS) as a source of complement, was added. After incubation for $15 \mathrm{~min}$ at $37^{\circ} \mathrm{C}$, opsonised bacteria were washed twice in PBS, resuspended in $500 \mu \mathrm{l}$ of HBSS and kept on ice until needed.

\section{Chemiluminescence (CL)}

Human neutrophil polymorphonuclear leukocytes (PMNL) were separated by dextran sedimentation (45 min at room temperature) from defibrinated venous blood taken from healthy adult volunteers. Residual red blood cells were lysed by treatment with tris-buffered ammonium chloride $0.83 \% \mathrm{w} / \mathrm{v}$ and, after washing, PMNL were resuspended in HBSS and counted, and the suspension adjusted to $2 \times 10^{6}$ cells $/ \mathrm{ml}$.

Luminol-dependent CL was performed as described previously (Easmon et al. 1980). The bacteria: PMN ratio was 100:1 and Luminol (Sigma) was used at a concentration of $2 \times 10^{-5} \mathrm{~mol} / 1$. Maximum CL produced was measured at $37^{\circ} \mathrm{C}$ with a Luminometer 1250 (LKB Instruments). Each experiment was repeated on five different occasions and data is presented as mean \pm SEM.

\section{Microscopial assay of phagocytosis}

Bacteria were mixed with PMN at a ratio of 10:1 and incubated at $37^{\circ} \mathrm{C}$ for $15 \mathrm{~min}$. Smears were prepared on glass slides by use of a cytocentrifuge (Shandon), fixed with methanol and stained with acridine orange $(0.3 \mathrm{mg} /$ $\mathrm{ml}$ ) in distilled water. At least $300 \mathrm{PMNL}$ were counted and the percentage of PMNLs with ingested bacteria was determined.

\section{Bacterial cell-surface hydrophobicity}

Bacterial cell-surface hydrophobicity was determined by measuring the affinity of bacteria toward octan-1-ol (Sigma) in an octan-l-ol/HBSS two-phase system (Rosenberg et al., 1980). Equal volumes of bacterial suspension and octan-1-ol were vortex mixed for $2 \mathrm{~min}$ and the phases allowed to separate for $30 \mathrm{~min}$ at room temperature. Absorbance of the bacterial suspension in the aqueous phase was determined at $540 \mathrm{~nm}\left(\mathrm{~A}_{540}\right)$. Bacterial suspensions without octan-1-ol were used to measure initial absorbance. The percentage hydrophobicity was calculated as follows: $\left(A_{540}\right.$ of initial suspension $-A_{540}$ of bacterial suspension after separation/ $A_{540}$ of initial bacterial suspension) $\times 100$.

\section{Results}

\section{Cross-reactivity of rabbit antiserum and $M A B S$}

To assess cross-reactivity, a direct binding RIA with heat-killed whole organisms was used. Immune rabbit serum (IRS) raised against the R595 mutant of $S$. minnesota cross-reacted with most of the gram-negative bacilli tested (table 1). Preimmune serum (NRS) showed some reactivity with the $R 4(R d 2), R 5(R c)$ and $R 345(R b 2)$ salmonella mutants, and with Citrobacter freundi, $E$. coli, Klebsiella pneumoniae and Serratia marcescens. 
However, apart from the R595 mutant, the level of direct binding of NRS was significantly lower than that of IRS.

Three MABs were tested against the same gramnegative organisms (table II). RE01 (IgM) was broadly reactive, RE12 (IgM) showed a more limited cross-reactivity, whereas RE23 (IgG2a) reacted with all clinical isolates tested except $B$. fragilis and $H$. influenzae. RE23 displayed a different pattern of reactivity with the salmonella mutants R595 ( Re) to R60 ( Ra) when compared with RE01 and RE12. As expected, a decrease in the level of binding and reactivity was seen along the series from the $R 595(\mathrm{Re})$ mutant to the parent wild type strain, presumably due to the core glycolipid immunodeterminant(s) becoming less accessible. In contrast, MABs RE01 and RE12 showed strong binding to the R595(Re), R4(Rd2) and R345(Rb2) mutants but poor binding to $R 5(R c), R 60(R a)$ and the parent wild type strain. An inhibition assay was also used to assess cross-reactivity of polyclonal serum and MABs. In this assay various concentrations of heat-killed organisms were pre-incubated with antibody (polyclonal or monoclonal) before transferring the mixture to RIA microtitration wells adsorbed with R595 cells. The results of a typical inhibition assay with RE12 is shown in fig. 1a. When the cross-reactivity of polyclonal serum and MABs by RIA was compared with the inhibition assay, good correlation was found between the two assays employed (presented in tables I and II). In all assays the homologous rough parent strain was an effective inhibitor, as was Ser. marcescens.

\section{Determination of epitope specificity}

Table III shows direct binding RIA results for MABs and polyclonal serum screened against various LPS and chemically-treated LPS preparations. All three MABs bound strongly to R595(Re), R345(Rb2) and BH-R595 LPS. RE23 reacted with all rough LPSs tested, while RE12 exhibited activity towards R4(Rd2) and R5(Rc). In comparison, IRS reacted with the rough LPSs in order of decreasing intensity from R595(Re) to R60(Ra). Neither this antiserum nor the MABs showed any binding to the homologous wild type LPS. RE23 bound strongly to free lipid A and all the chemicallytreated LPS preparations, suggesting that it recognised one or more immunodeterminants in the $\mathrm{N}$ acetyl-D-glucosamine backbone of lipid A. In contrast, RE01 and RE12 did not bind to the reduced-R595 LPS. This suggests that the immunodeterminant recognised is the KDO moiety. However, RE01 also showed a slight reactivity with

Table I. Taxonomic specificity of rabbit polyclonal antiserum raised against $S$. minnesota R595 in a direct binding and inhibition RIA with heat-killed bacteria as antigen and inhibitor

\begin{tabular}{|c|c|c|c|c|}
\hline \multirow{3}{*}{$\begin{array}{l}\text { Bacteria } \\
\text { S. minnesota } \mathrm{R} 595(\mathrm{Re}) \\
\text { S. minnesota } \mathrm{R} 4(\mathrm{Rd} 2) \\
\text { S. minnesota } \mathrm{R} 5(\mathrm{Rc}) \\
\text { S. minnesota } \mathrm{R} 345(\mathrm{Rb} 2) \\
\text { S. minnesota } \mathrm{R} 60(\mathrm{Ra}) \\
\text { S. minnesota } \text { wild type }\end{array}$} & \multicolumn{4}{|c|}{$\begin{array}{c}\text { Direct cpm (mean } \pm \text { SEM) and percentage inhibition } \\
( \pm \text { SEM }) \text { with }\end{array}$} \\
\hline & \multicolumn{2}{|c|}{ immune rabbit serum } & \multicolumn{2}{|c|}{ normal rabbit serum } \\
\hline & $\begin{array}{ll}7 & 249 \pm 60 \\
3 & 560 \pm 30 \\
1 & 213 \pm 54 \\
1 & 064 \pm 20 \\
1 & 099 \pm 60 \\
1 & 337 \pm 44\end{array}$ & $\begin{array}{l}75( \pm 5) \% \\
56( \pm 3) \% \\
50( \pm 5) \% \\
50( \pm 14) \% \\
50( \pm 4) \% \\
42( \pm 7) \%\end{array}$ & $\begin{array}{c}1143 \pm 15 \\
766 \pm 10 \\
548 \pm 32 \\
327 \pm 18 \\
299 \pm 7 \\
145 \pm 17\end{array}$ & $\begin{array}{c}70( \pm 20) \% \\
20( \pm 2) \% \\
20( \pm 4) \% \\
25( \pm 5) \% \\
10( \pm 1) \% \\
7( \pm 2) \%\end{array}$ \\
\hline $\begin{array}{l}\text { Ser. marcescens } \\
\text { C. freundi } \\
\text { N. meningitidis } \\
\text { Enterobacter cloacae } \\
\text { E. coli } \\
\text { Ps. aeruginosa } \\
\text { Proteus mirabilis } \\
\text { K. pneumoniae } \\
\text { H. influenzae type b } \\
\text { B. fragilis }\end{array}$ & $\begin{array}{l}4430 \pm 50 \\
1512 \pm 38 \\
1289 \pm 25 \\
1150 \pm 40 \\
1100 \pm 10 \\
1000 \pm 14 \\
890 \pm 20 \\
800 \pm 56 \\
580 \pm 40 \\
217 \pm 6\end{array}$ & $\begin{array}{l}55( \pm 5) \% \\
30( \pm 5) \% \\
19( \pm 3) \% \\
27( \pm 9) \% \\
27( \pm 2) \% \\
20( \pm 8) \% \\
12( \pm 2) \% \\
20( \pm 3) \% \\
10( \pm 4) \% \\
7( \pm 1) \%\end{array}$ & $\begin{array}{l}585 \pm 10 \\
340 \pm 19 \\
240 \pm 5 \\
379 \pm 17 \\
679 \pm 30 \\
100 \pm 26 \\
227 \pm 40 \\
390 \pm 4 \\
212 \pm 30 \\
96 \pm 12\end{array}$ & $\begin{array}{c}32( \pm 12) \% \\
27( \pm 9) \% \\
12( \pm 3) \% \\
10( \pm 5) \% \\
30( \pm 21) \% \\
4( \pm 1) \% \\
4( \pm 1) \% \\
22( \pm 15) \% \\
4( \pm 1) \% \\
0\end{array}$ \\
\hline $\begin{array}{l}\text { Streptococcus faecalis } \\
\text { Staphylococcus aureus }\end{array}$ & $\begin{array}{l}400 \pm 56 \\
169 \pm 12\end{array}$ & $\begin{array}{l}0 \\
0\end{array}$ & $\begin{array}{l}160 \pm 27 \\
159 \pm 23\end{array}$ & $\begin{array}{l}0 \\
0\end{array}$ \\
\hline
\end{tabular}


Table II. Taxonomic specificity of MAB RE01, RE12 and RE23 in direct binding and inhibition RIA with heatkilled bacteria as antigen and inhibitor

\begin{tabular}{|c|c|c|c|c|c|c|}
\hline \multirow{3}{*}{$\begin{array}{l}\text { Bacteria } \\
\text { S. minnesota } \mathrm{R} 595(\mathrm{Re}) \\
\text { S. minnesota } \mathrm{R} 4(\mathrm{Rd} 2) \\
\text { S. minnesota } \mathrm{R} 5(\mathrm{Rc}) \\
\text { S. minnesota } \mathrm{R} 345(\mathrm{Rb} 2) \\
\text { S. minnesota } \mathrm{R} 60(\mathrm{Ra}) \\
\text { S. minnesota } \text { wild type }\end{array}$} & \multicolumn{6}{|c|}{ Direct cpm (mean \pm SEM) and percentage inhibition $( \pm S E M)$ with } \\
\hline & \multicolumn{2}{|c|}{ RE01(IgM) } & \multicolumn{2}{|c|}{ RE12(IgM) } & \multicolumn{2}{|c|}{ RE23(IgG2a) } \\
\hline & $\begin{array}{c}7064 \pm 120 \\
760 \pm 20 \\
340 \pm 17 \\
4207 \pm 100 \\
310 \pm 9 \\
334 \pm 10\end{array}$ & $\begin{array}{l}56( \pm 2) \% \\
27( \pm 2) \% \\
21( \pm 1) \% \\
50( \pm 4) \% \\
10( \pm 3) \% \\
5( \pm 1) \%\end{array}$ & $\begin{array}{r}6503 \pm 60 \\
2000 \pm 10 \\
658 \pm 12 \\
3986 \pm 60 \\
350 \pm 15 \\
216 \pm 10\end{array}$ & $\begin{array}{r}62( \pm 8) \% \\
30( \pm 5) \% \\
14( \pm 4) \% \\
30( \pm 5) \% \\
9( \pm 1) \% \\
7( \pm 1) \%\end{array}$ & $\begin{array}{ll}7 & 450 \pm 121 \\
2 & 065 \pm 19 \\
1 & 760 \pm 25 \\
1 & 295 \pm 40 \\
1 & 200 \pm 10 \\
1 & 215 \pm 15\end{array}$ & $\begin{array}{l}64( \pm 18) \% \\
37( \pm 5) \% \\
32( \pm 4) \% \\
24( \pm 2) \% \\
17( \pm 2) \% \\
15( \pm 3) \%\end{array}$ \\
\hline $\begin{array}{l}\text { Ser. marcescens } \\
\text { C. freundii } \\
\text { N. meningitidis } \\
\text { E. cloacae } \\
\text { E. coli } \\
\text { Ps. aeruginosa } \\
P . \text { mirabilis } \\
\text { K. pneumoniae } \\
\text { H. influenzae type b } \\
\text { B. fragilis }\end{array}$ & $\begin{array}{c}4056 \pm 58 \\
3060 \pm 100 \\
816 \pm 12 \\
1000 \pm 14 \\
1756 \pm 160 \\
600 \pm 18 \\
1151 \pm 40 \\
1010 \pm 12 \\
210 \pm 20 \\
159 \pm 20\end{array}$ & $\begin{array}{l}40( \pm 10) \% \\
35( \pm 16) \% \\
15( \pm 4) \% \\
27( \pm 6) \% \\
27( \pm 4) \% \\
15( \pm 4) \% \\
10( \pm 2) \% \\
25( \pm 1) \% \\
5( \pm 1) \% \\
6( \pm 1) \%\end{array}$ & $\begin{array}{c}1363 \pm 20 \\
2110 \pm 30 \\
1059 \pm 25 \\
1419 \pm 28 \\
578 \pm 20 \\
273 \pm 5 \\
529 \pm 10 \\
1005 \pm 10 \\
570 \pm 32 \\
113 \pm 20\end{array}$ & $\begin{array}{l}30( \pm 5) \% \\
28( \pm 2) \% \\
18( \pm 7) \% \\
24( \pm 5) \% \\
18( \pm 7) \% \\
10( \pm 4) \% \\
12( \pm 2) \% \\
26( \pm 5) \% \\
6( \pm 2) \% \\
5( \pm 1) \%\end{array}$ & $\begin{array}{r}2000 \pm 10 \\
1226 \pm 25 \\
2060 \pm 42 \\
1406 \pm 30 \\
1819 \pm 60 \\
1260 \pm 12 \\
1159 \pm 26 \\
2120 \pm 18 \\
180 \pm 10 \\
90 \pm 10\end{array}$ & $\begin{array}{l}34( \pm 2) \% \\
18( \pm 2) \% \\
20( \pm 5) \% \\
15( \pm 4) \% \\
10( \pm 2) \% \\
12( \pm 2) \% \\
20( \pm 1) \% \\
24( \pm 6) \% \\
5( \pm 2) \% \\
3( \pm 1) \%\end{array}$ \\
\hline $\begin{array}{l}\text { Str. faecalis } \\
\text { Staph. aureus }\end{array}$ & $\begin{array}{r}60 \pm 15 \\
100 \pm 30\end{array}$ & $\begin{array}{l}0 \\
0\end{array}$ & $\begin{array}{r}120 \pm 12 \\
90 \pm 10\end{array}$ & $\begin{array}{l}0 \\
0\end{array}$ & $\begin{array}{l}189 \pm 47 \\
200 \pm 70\end{array}$ & $\begin{array}{l}0 \\
0\end{array}$ \\
\hline
\end{tabular}

free lipid $\mathrm{A}$ and $\mathrm{BH}$-lipid $\mathrm{A}$, indicating that lipid $\mathrm{A}$ may be structurally important for recognition of the immunodeterminant. IRS also had activity against free lipid A and most of the chemicallytreated LPS preparations. However, treatment of LPS and free lipid A with alkali led to a dramatic reduction in binding of IRS. The predominant antibody activity of IRS may, therefore, be directed against the KDO moiety and the ester-linked fatty acids. Again to confirm direct binding results, inhibition RIAs were performed with LPS and chemically-treated LPS preparations as inhibitors.
Typical inhibition curves obtained with RE12 are presented in fig. $1 b$.

\section{Opsonisation of rough and smooth strains of $S$. minnesota with polyclonal antiserum}

Table IV shows the results obtained before and after treatment of $S$. minnesota wild type and the R595 mutant with heat-inactivated and unheated NRS and IRS. As expected, the rough mutant was very hydrophobic. This probably accounts for the discrepancy between the high level of chemilumi-

Table III. Molecular specificity of immune rabbit serum (IRS) and MABs RE01, RE12 and RE23 in a direct binding and inhibition RIA with LPS and chemically-treated LPS as antigen and inhibitor

\begin{tabular}{|c|c|c|c|c|c|c|c|c|}
\hline \multirow{3}{*}{$\begin{array}{l}\text { Bacteria } \\
\text { S. minnesota R595 (Re) LPS }\end{array}$} & \multicolumn{8}{|c|}{ Direct cpm $($ mean + SEM $)$ and percentage inhibition $( \pm$ SEM $)$ with } \\
\hline & \multicolumn{2}{|c|}{ MAB RE01 (IgM) } & \multicolumn{2}{|c|}{ MAB RE12 (IgM) } & \multicolumn{2}{|c|}{ MAB RE23 (IgG2a) } & \multicolumn{2}{|c|}{ Polyclonal IRS } \\
\hline & $4596 \pm 120$ & $57( \pm 5) \%$ & $5670 \pm 57$ & $60( \pm 9) \%$ & $6450 \pm 90$ & $60( \pm 10) \%$ & $3340 \pm 10$ & $88( \pm 5) \%$ \\
\hline S. minnesota R4 (Rd2) LPS & $507 \pm 40$ & $8( \pm 0.7) \%$ & $1200 \pm 20$ & $24( \pm 2) \%$ & $3610 \pm 50$ & $42( \pm 5) \%$ & $1206 \pm 18$ & $52( \pm 5) \%$ \\
\hline S. minnesota R5 (Rc) LPS & $670 \pm 20$ & $12( \pm 4) \%$ & $470 \pm 17$ & $22( \pm 7) \%$ & $2000 \pm 130$ & $22( \pm 2) \%$ & $649 \pm 12$ & $32( \pm 2) \%$ \\
\hline S. minnesota R345 (Rb2) LPS & $2200 \pm 60$ & $40( \pm 5) \%$ & $2400 \pm 40$ & $30( \pm 2) \%$ & $4350 \pm 100$ & $45( \pm 7) \%$ & $990 \pm 10$ & $20( \pm 8) \%$ \\
\hline S. minnesota $\mathrm{R} 60(\mathrm{Ra}) \mathrm{LPS}$ & $200 \pm 10$ & $10( \pm 0 \cdot 1) \%$ & $410 \pm 10$ & $10( \pm 1) \%$ & $1100 \pm 50$ & $23( \pm 2) \%$ & $712 \pm 20$ & $17( \pm 1) \%$ \\
\hline S. minnesota Wild Type LPS & $170 \pm 15$ & $7( \pm 0.5) \%$ & $200 \pm 12$ & $8( \pm 0.4) \%$ & $990 \pm 20$ & $17( \pm 6) \%$ & $547 \pm 17$ & $8( \pm 2) \%$ \\
\hline BH-R595 LPS & $3259 \pm 24$ & $47( \pm 10) \%$ & $5610 \pm 80$ & $52( \pm 10) \%$ & $4272 \pm 60$ & $37( \pm 4) \%$ & $689 \pm 10$ & $27( \pm 5) \%$ \\
\hline Reduced-R595 LPS & $90 \pm 12$ & $2( \pm 0.4) \%$ & $100 \pm 20$ & 0 & $6328 \pm 112$ & $50( \pm 8) \%$ & $1237 \pm 20$ & $38( \pm 7) \%$ \\
\hline Free Lipid A & $996 \pm 30$ & $25( \pm 7) \%$ & $130 \pm 10$ & $1( \pm 0 \cdot 1) \%$ & $5812 \pm 48$ & $50( \pm 10) \%$ & $1127 \pm 10$ & $35( \pm 5) \%$ \\
\hline BH-Lipid A & $840 \pm 10$ & $20( \pm 2) \%$ & $97 \pm 5$ & $2( \pm 0.4) \%$ & $4169 \pm 35$ & $34( \pm 5) \%$ & $713 \pm 9$ & $24( \pm 5) \%$ \\
\hline
\end{tabular}




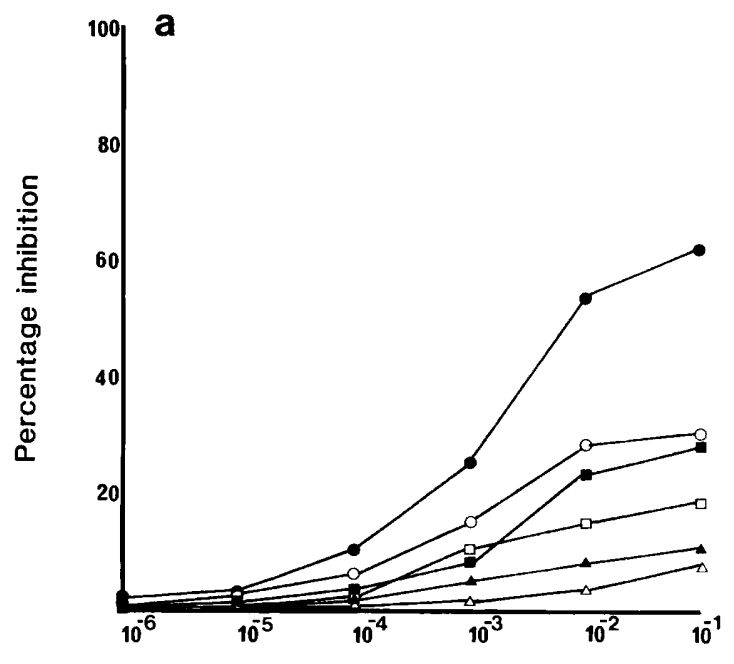

Dilution of bacterial suspension

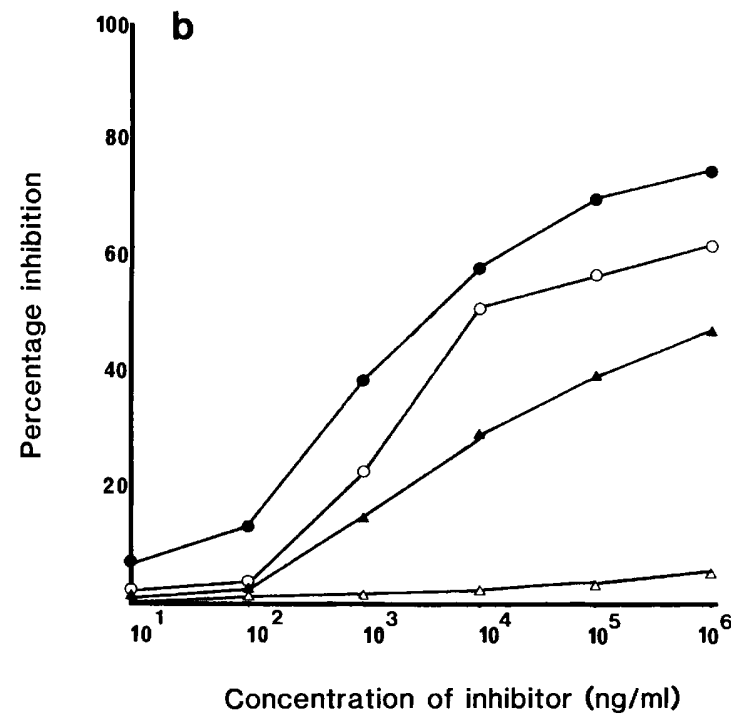

Figure. Inhibition assay, the percentage inhibition of binding of MAB RE12 by (a) $S$. minnesota R595 (O); Ser. marcescens (O); $C$. freundi $(\square) ; E$. coli $(\square) ; P$ s. aeruginosa $(\Lambda)$ and $S$. minnesota wild type $(\triangle)$ bacterial suspensions, and (b) $S$. minnesota $R 595$ LPS (O); BH-R595 LPS (O); S. minnesota R345 LPS (A) and free lipid $A(\triangle)$.

nescence and the moderate degree of ingestion of the untreated organisms. Microscopy showed that many bacteria were adherent to but not ingested by neutrophils. This adherence may well have provided the membrane stimulus for chemiluminescence. In comparison with untreated organisms, treatment with NRS reduced chemiluminescence and phagocytic uptake. Again this may be linked to the reduction in hydrophobicity of the unopson- ised organisms. Heat-labile factors would appear to be involved because the effect was lost with heated NRS.

IRS was opsonic. The microscopic phagocytic uptake assay showed this to be largely complementindependent while enhancement of chemiluminescence was complement-dependent. With the smooth (non-hydrophobic) wild type $S$. minnesota, unopsonised organisms were poorly ingested as were those treated with NRS. However, treatment with NRS triggered an apparently complement-dependent enhancement of chemiluminescence. IRS did not opsonise wild type $S$. minnesota in the absence of complement. This effect was not as marked as with the rough mutant.

\section{Opsonisation of $S$. minnesota with $M A B S$}

None of the MABs showed any significant opsonic activity against the homologous rough parent strain in the presence or absence of complement (table V). However, with RE01 there was a significant enhancement of chemiluminescence, but without any corresponding increase in bacterial ingestion. None of the MABs were opsonic for the $S$. minnesota wild type strain (results not shown).

\section{Discussion}

Antisera raised against the rough mutants of $E$. coli O111: B4 (E. coli J5) and S. minnesota ( $S$. minnesota R595) protect animals and man against bacteraemia with gram-negative bacilli (Nelles and Niswander, 1984), although results have not always been consistent (McCutchan et al., 1983; Zinner and Peter, 1983). Neither the mechanism by which these antisera exert their protective effects nor the immunodeterminant(s) against which they are directed have been resolved (Wolff, 1982). Knowledge of both is important for the logical development of protective monoclonal reagents. Two likely protective mechanisms have been suggestedantitoxic immunity directed against the pathophysiological effects of LPS (Ziegler et al., 1982; Johns et al., 1983) and antibacterial immunity, e.g., opsonisation and phagocytosis (Crowley et al., 1982). Current clinical evidence favours the former because protection has been directed mainly against fatal bacteriogenic shock (Baumgartner et al., 1985).

Our results show that rabbit antiserum against $S$. minnesota R595 opsonises both the homologous strain and the wild type parent strain. This antiserum reacts with many other gram-negative 
Table IV. Phagocytic uptake PMNL chemiluminescence induction and hydrophobicity of $S$. minnesota wild type and the R595 (Re) mutant after treatment with normal rabbit serum (NRS) and immune rabbit serum (IRS)

\begin{tabular}{|c|c|c|c|c|c|c|}
\hline \multirow[b]{2}{*}{ Opsonin source } & \multicolumn{3}{|c|}{ S. minnesota wild type } & \multicolumn{3}{|c|}{ S. minnesota $\mathrm{R} 595(\mathrm{Re})$} \\
\hline & $\begin{array}{l}\text { Phagocytosis } \\
(\% \pm \text { SEM) }\end{array}$ & $\begin{array}{c}\mathrm{CL} \\
(\mathrm{mV} \pm \mathrm{SEM})\end{array}$ & $\begin{array}{c}\text { Hydrophobicity } \\
(\% \pm \text { SEM) }\end{array}$ & $\begin{array}{c}\text { Phagocytosis } \\
(\% \pm \text { SEM) }\end{array}$ & $\begin{array}{c}\mathrm{CL} \\
(\mathrm{mV} \pm \mathrm{SEM})\end{array}$ & $\begin{array}{c}\text { Hydrophobicity } \\
\text { (\% } \% \text { SEM) }\end{array}$ \\
\hline $\begin{array}{l}\text { Unopsonised } \\
\text { NRS } 10 \% \\
\text { H. NRS } 10 \% \\
\text { IRS } 10 \% \\
\text { H. IRS } 10 \%\end{array}$ & $\begin{array}{l}13 \pm 0 \cdot 3 \\
18 \pm 0 \cdot 7 \\
14 \pm 0 \cdot 4 \\
40 \pm 1 \cdot 0 \\
22 \pm 0.4\end{array}$ & $\begin{array}{c}29 \pm 3 \\
186 \pm 17 \\
52 \pm 5 \\
151 \pm 20 \\
80 \pm 9\end{array}$ & $\begin{array}{r}0 \cdot 2 \pm 0 \cdot 1 \\
38 \pm 0 \cdot 6 \\
0 \cdot 7 \pm 0 \cdot 2 \\
67 \pm 1 \cdot 0 \\
80 \pm 0 \cdot 8\end{array}$ & $\begin{array}{l}39 \pm 0.8 \\
25 \pm 0.4 \\
34 \pm 0.6 \\
78 \pm 1 \cdot 0 \\
66 \pm 0.5\end{array}$ & $\begin{aligned} 200 & \pm 20 \\
20 & \pm 3 \\
80 & \pm 10 \\
180 & \pm 25 \\
80 & \pm 12\end{aligned}$ & $\begin{array}{l}80 \pm 0 \cdot 6 \\
65 \pm 1 \cdot 0 \\
50 \pm 0 \cdot 8 \\
45 \pm 0 \cdot 8 \\
63 \pm 0 \cdot 9\end{array}$ \\
\hline
\end{tabular}

H.NRS and $\mathrm{H} . \mathrm{IRS}=$ heat-inactivated serum $\left(56^{\circ} \mathrm{C}\right.$ for $\left.30 \mathrm{~min}\right)$.

Table V. Phagocytic uptake and PMNL chemiluminescence induction of $S$. minnesota R595 (Re) after treatment with MABs RE01, RE12 and RE23

\begin{tabular}{|c|c|c|c|c|c|c|}
\hline \multirow[b]{2}{*}{ Opsonin } & \multicolumn{2}{|c|}{ MAB RE01 } & \multicolumn{2}{|c|}{ MAB RE12 } & \multicolumn{2}{|c|}{ MAB RE23 } \\
\hline & $\begin{array}{l}\text { Phagocytosis } \\
(\% \pm \text { SEM) }\end{array}$ & $\begin{array}{c}\mathrm{CL} \\
(\mathrm{mV} \pm \mathrm{SEM})\end{array}$ & $\begin{array}{l}\text { Phagocytosis } \\
\text { (\% } \pm \text { SEM) }\end{array}$ & $\begin{array}{c}\mathrm{CL} \\
(\mathrm{mV} \pm \mathrm{SEM}\end{array}$ & $\begin{array}{c}\text { Phagocytosis } \\
(\% \pm \text { SEM) }\end{array}$ & $\begin{array}{c}\mathrm{CL} \\
(\mathrm{mV} \pm \mathrm{SEM})\end{array}$ \\
\hline $\begin{array}{l}\text { Unopsonised } \\
\text { MAB } \\
\text { MAB + baby rabbit serum } \\
10 \%\end{array}$ & $\begin{array}{l}39 \pm 0 \cdot 6 \\
48 \pm 0 \cdot 4 \\
26 \pm 0 \cdot 2\end{array}$ & $\begin{array}{l}220 \pm 25 \\
150 \pm 10 \\
440 \pm 37\end{array}$ & $\begin{array}{l}30 \pm 0.5 \\
35 \pm 0.4 \\
27 \pm 0.7\end{array}$ & $\begin{array}{c}142 \pm 27 \\
40 \pm 9 \\
52 \pm 4\end{array}$ & $\begin{array}{l}28 \pm 0 \cdot 6 \\
30 \pm 0 \cdot 3 \\
32 \pm 1\end{array}$ & $\begin{array}{r}220 \pm 31 \\
-170 \pm 15 \\
210 \pm 28\end{array}$ \\
\hline $\begin{array}{l}\text { Baby rabbit serum } 10 \% \\
\text { Baby rabbit serum heated at } \\
56^{\circ} \mathrm{C} \text { for } 30 \text { min }\end{array}$ & $\begin{array}{l}23 \pm 0 \cdot 1 \\
29 \pm 1\end{array}$ & $\begin{array}{l}55 \pm 14 \\
52 \pm 12\end{array}$ & $\begin{array}{l}20 \pm 0 \cdot 4 \\
17 \pm 0 \cdot 2\end{array}$ & $\begin{array}{l}38 \pm 5 \\
40 \pm 5\end{array}$ & $\begin{array}{l}20 \pm 0 \cdot 9 \\
30 \pm 2\end{array}$ & $\begin{array}{l}53 \pm 10 \\
50 \pm 9\end{array}$ \\
\hline
\end{tabular}

bacilli. It also reacts with LPS from a range of gram-negative bacilli and LPS preparations which have been treated chemically. We do not know the fine molecular specificity, although our results suggest that the predominant activity is directed against the core polysaccharide and the ester-linked fatty acids of lipid A.

The three monoclonal reagents RE01, RE12 and RE23 did not opsonise the homologous R595 mutant or the smooth $S$. minnesota. Whereas RE23 recognises an epitope(s) within the $\mathrm{N}$-acetyl-Dglucosamine backbone of lipid A, RE01 and RE12 bind principally to the KDO moiety. These three antibodies, which represent the most likely isotypes relevant to opsonisation, all have targets within the core glycolipid. Their failure to opsonise the R595 mutant, which clearly has these structures exposed on the surface, could mean that the specific epitope recognised is either inappropriate or insufficient in density for efficient opsonisation. A cocktail of MABs with different isotypes and core glycolipid specificity has also been investigated and it also failed to opsonise (data not shown). Another explanation could be that the antibodies may simply not be opsonic, although with an $\operatorname{IgM}$ this is perhaps unlikely (Polin and Harris, 1985). One key factor in resolving this dilemma is to determine whether the opsonic activity of the rabbit antiserum is related to targets within the core glycolipid or to other common determinants within the cell wall of gram-negative bacteria. This is currently being investigated by absorption studies.

In measuring opsonisation we found significant discrepancies between results with luminol-dependent chemiluminescence and the microscopic assay of phagocytosis. With the rough R595 mutant, unopsonised organisms stimulated marked chemiluminescence, but only moderate phagocytic uptake. Microscopy showed that most of the organisms were adhering to the surfaces of neutrophils, with relatively few ingested. This adherence is probably related to the extreme hydrophobicity of the rough mutants. Treatment of the R595 mutant with non-immune serum depressed chemiluminescence and phagocytic uptake. This surprising observation appeared to depend, at least partly, 
on the reduction in surface hydrophobicity following incubation with normal serum, and partly on the interaction of heat-labile serum components with the bacterial surface, because the effect was lost when serum was heat-inactivated. Another discrepancy between chemiluminescence and phagocytosis was seen with immune serum. Opsonisation of the R595 mutant appeared to be complement dependent when measured by chemiluminescence, but complement-independent when measured by phagocytosis. Clark and Easmon (1986) found complement to be necessary for the stimulation of luminol-dependent chemiluminescence by opsonised bacteria. They found that high concentrations of opsonic immunoglobulin alone failed to stimulate

\section{REFERENCES}

Baumgartner J D et al. 1985 Prevention of gram-negative shock and death in surgical patients by antibody to endotoxin core glycolipid. Lancet 2: 59-63.

Braude A I, Ziegler E J, Douglas H, McCutchan J A 1977 Antibody to cell wall glycolipid of gram-negative bacteria: Induction of immunity to bacteremia and endotoxemia. Journal of Infectious Diseases 136 (Suppl): S167-S173.

Clark L A, Easmon C S F 1986 Opsonic activity of intravenous immunoglobulin preparations against Staphylococcus epidermidis. Journal of Clinical Pathology 39: 856-860.

Crowley J P, Zinner S H, Peter G 1982 Opsonization of serumsensitive and serum-resistant Escherichia coli by rough mutant (Re) antisera. Journal of Laboratory and Clinical Medicine 99: 197-205.

Dunn D L, Bogard W C, Cerra F B 1985 Enhanced survival during murine gram-negative bacterial sepsis by use of a murine monoclonal antibody. Archives of Surgery 120: 5053.

Easmon C S F, Cole P J, Williams A J, Hastings M 1980 The measurement of opsonic and phagocytic function by luminol-dependent chemiluminescence. Immunology 41: 67-74.

Galanos C, Lüderitz O, Westphal O 1969 A new method for the extraction of R-lipopolysaccharides. European Journal of Biochemistry 9: 245-249.

Galanos C, Lüderitz O, Westphal O 1971 Preparation and properties of antisera against the lipid-A component of bacterial lipopolysaccharides. European Journal of Biochemistry 24: 116-122.

Galanos C, Rietschel E T, Lüderitz O, Westphal O Kim Y B, Watson D W 1972 Biological activities of lipid A complexed with bovine-serum albumin. European Journal of Biochemistry 31 : 230-233.

Galfrè G, Milstein C 1982 Chemical typing of human kappa light chain subgroups expressed by human hybrid myelomas. Immunology 45: 125-128.

Greisman S E, Dubuy J B, Woodward C L 1978 Experimental gram-negative bacterial sepsis: Re-evaluation of the ability of rough mutant antisera to protect mice. Proceedings of the Society for Experimental Biology and Medicine 158: 482-490.

Ivanyi J, Davies P 1980 Monoclonal antibodies against human growth hormone. Molecular immunology 17: 287-290.

Johns M, Skehill A, McCabe W R 1983 Immunization with rough mutants of Salmonella minnesota. IV. Protection by chemiluminescence despite microscopical evidence of bacterial uptake.

Chemiluminescence has been used frequently to measure opsonic function. Our results show that care should be taken in interpreting results obtained with hydrophobic organisms or with antibody driven systems in the absence of complement. We recommend that an independent assay of phagocytosis should always be used in conjunction with chemiluminescence.

This work was supported by an SERC (CASE) grant awarded to N.D.M. in collaboration with the Wellcome Research Laboratories. We thank R.M. Lifely for his valuable discussions and, particularly, B. J. Appelmelk for his collaboration and generous gift of monoclonal antibody RE23.

antisera to $\mathrm{O}$ and rough antigens against endotoxin. Journal of Infectious Diseases 147 : 57-67.

Kirkland T N, Ziegler E J 1984 An immunoprotective monoclonal antibody to lipopolysaccharide. Journal of Immunology 132: 2590-2592.

Kreger B E, Craven D E, Carling P C, McCabe W R $1980 a$ Gram-negative bacteremia. III. Reassessment of etiology, epidemiology and ecology in 612 patients. American Journal of Medicine 68: 332-343.

Kreger B E, Craven D E, McCabe W R $1980 b$ Gram-negative bacteremia. IV. Re-evaluation of clinical features and treatment in 612 patients. American Journal of Medicine 68 : 344-355.

McCabe W R, Burns S C, Craven D E, Johns M 1977 Crossreactive antigens : their potential for immunization-induced immunity to gram-negative bacteria. Journal of Infectious Diseases 136: S161-S166.

McCutchan J A, Wolf J L, Ziegler E J, Braude A I 1983 Ineffectiveness of single-dose human antiserum to core glycolipid (Escherichia coli J5) for prophylaxis of bacteremic, gram-negative infections in patients with prolonged neutropenia. Schweizerische Medizinische Wochenschrift Suppl 14: 40-45.

Nelles M J, Niswander C A 1984 Mouse monoclonal antibodies reactive with $\mathrm{J} 5$ lipopolysaccharide exhibit extensive serological cross-reactivity with a variety of gram-negative bacteria. Infection and Immunity 46: 677-681.

$\mathrm{Ng} \mathrm{A}$, Chen C L H, Chang C M, Nowotny A 1976 Relationship of structure to function in bacterial endotoxins: Serologically cross-reactive components and their effect on protection of mice against some gram-negative infections. Journal of General Microbiology 94: 107-116.

Pennington J E, Menkes E 1981 Type-specific vs cross-protective vaccination for gram-negative bacterial pneumonia. Journal of Infectious Diseases 144: 599-603.

Polin R A, Harris C M 1985 Monoclonal antibodies against Group B streptococcus. In: Macario A J L, Macario E C (eds) Monoclonal antibodies against bacteria, vol 1 . Academic Press, Orlando, FL, pp. 37-58.

Rietschel E T, Sidorczyk Z, Zähringer U, Wollenweber H-W, Lüderitz O, 1983 Analysis of the primary structure of lipid A. In: Anderson L, Unger F M (eds) Bacterial lipopolysaccharides. Structure, synthesis, biological activities. American Chemical Society Symposium Series 231, American Chemical Society, Washington, D.C. pp 195-218. 
Rosenberg M, Gutnick D, Rosenberg E 1980 Adherence of bacteria to hydrocarbons: A simple method for measuring cell-surface hydrophobicity. FEMS Microbiology Letters 9: 29-33.

Taylor R L, Conrad H E 1972 Stoichiometric depolymerization of polyuronides and glucosaminoglycuronans to monosaccharides following reduction of their carbodiimide-activated carboxyl groups. Biochemistry 11 : 1383-1388.

Teng N N H et al. 1985 Protection against gram-negative bacteremia and endotoxemia with human monoclonal IgM antibodies. Proceedings of the National Academy of Sciences of the USA 82: 1790-1794.

Van Dijk W C, Verbrugh H A, Van Erne-Van Der Tol M E, Peters R, Verhoef J 1981 Escherichia coli antibodies in opsonisation and protection against infection. Journal of Medical Microbiology 14: 381-389.

Westphal O, Jann K 1965 Bacterial lipopolysaccharides. Extraction with phenol-water and further applications of the procedure. In Whistler R L (ed) Methods in Carbohy- drate Chemistry, vol 5. Academic Press, New York, pp. 83-91.

Wolff S M 1982 The treatment of gram-negative bacteremia and shock (editorial). New England Journal of Medicine 307: 1267-1268.

Ziegler E J, Douglas H, Sherman J E, Davis C E, Braude A I 1973 Treatment of $E$. coli and Klebsiella bacteremia in agranulocytic animals with antiserum to a UDP-Gal epimerase-deficient mutant. Journal of Immunology 111 : 433-438.

Ziegler E J, McCutchan J A, Fierer J, Glauser M P, Sadoff J C, Douglas H, Braudé A I 1982 Treatment of gram negative bacteraemia and shock with human antiserum to a mutant Escherichia coli. New England Journal of Medicine 307: 12251228.

Zinner S H, Peter G 1983 The potential role of cell wall core glycoplipids in the immunoprophylaxis and therapy of gram-negative rod bacteraemia. In: Easmon $\mathrm{C} S \mathrm{~F}$, Jeljaszewicz J (eds) Medical Microbiology, vol II. Academic Press, London, pp. 71-85. 